\title{
Spatial and temporal distributions of total and methyl mercury in precipitation in core urban areas, Chongqing, China
}

\author{
Y. M. Wang ${ }^{1}$, D. Y. Wang ${ }^{1,2}$, B. Meng ${ }^{3}$, Y. L. Peng ${ }^{1}$, L. Zhao ${ }^{1}$, and J. S. Zhu ${ }^{1}$ \\ ${ }^{1}$ Key Laboratory of the Three Gorges Reservoir Region's Eco-Environment (Ministry of Education), College of Resources \\ and Environment, Southwest University, Chongqing 400715, China \\ ${ }^{2}$ Chongqing Key Laboratory of Agricultural Resources and Environment, Chongqing 400716, China \\ ${ }^{3}$ State Key Laboratory of Environmental Geochemistry, Institute of Geochemistry, Chinese Academy of Sciences, \\ Guiyang 550002, China
}

Correspondence to: D. Y. Wang (dywang@swu.edu.cn)

Received: 23 February 2012 - Published in Atmos. Chem. Phys. Discuss.: 20 April 2012

Revised: 5 August 2012 - Accepted: 21 September 2012 - Published: 18 October 2012

\begin{abstract}
The spatial and temporal distribution patterns of mercury $(\mathrm{Hg})$ in precipitation were investigated in the core urban areas of Chongqing, China. During the period from July 2010 to June 2011, total mercury (THg) and methyl mercury $(\mathrm{MeHg})$ concentrations in precipitation were analysed from three sampling sites. Our results suggested that the volume-weight mean $\mathrm{THg}$ and $\mathrm{MeHg}$ concentrations in precipitation were $30.67 \mathrm{ng} \mathrm{l}^{-1}$ and $0.31 \mathrm{ng} \mathrm{l}^{-1}$, respectively. The proportion of $\mathrm{MeHg}$ in $\mathrm{THg}$ ranged from $0.1 \%$ to $7.6 \%$ with a mean value of $1.3 \%$. THg and $\mathrm{MeHg}$ concentrations showed seasonal variations, while the highest $\mathrm{THg}$ value was measured in winter. Contrarily, the highest $\mathrm{MeHg}$ concentration was observed in autumn. Additionally, a geographically gradual decline of $\mathrm{THg}$ concentration in precipitation was observed from the downtown to the suburb, then to the controlled site in the city. $5 \mathrm{~mm}$ rainfall might be a threshold for the full wash-out capability. Rainfall above $5 \mathrm{~mm}$ may have a diluting effect for the concentrations of THg. Moreover, the current research implies that the coal combustion and motor vehicles could be the dominant sources for $\mathrm{Hg}$ in the precipitation.
\end{abstract}

\section{Introduction}

Mercury ( $\mathrm{Hg}$ ) pollution, a global issue, poses potential threats to human health and wildlife (National Research Council, 2000). Hg species, including gaseous element mercury $\left(\mathrm{Hg}^{0}\right)$, reactive gaseous mercury (RGM), and partic- ulate mercury $(\mathrm{PHg})$, are commonly represented in the atmosphere (Lindberg et al., 2007). The primary mechanisms for wet deposition are: (1) in-cloud oxidation of $\mathrm{Hg}^{0}$ by $\mathrm{O}_{3}$, (2) gas-phase oxidation of $\mathrm{Hg}^{0}$ by $\cdot \mathrm{OH}$ and $\mathrm{O}_{3}$ followed by cloud-droplet uptake. Dissolved mercury (DHg) and PHg are the major forms of $\mathrm{Hg}$ in precipitation, where the later one can be deposited through cloud-droplet/precipitation scavenging activity (Lindberg et al., 2007).

MeHg generally accounts for $\sim 0.5-3.0 \%$ of THg in precipitation (Mason et al., 2000; St. Louis et al., 2005; Nguyen et al., 2005; Munthe et al., 1995a, b), but the proportion can be $>10 \%$ in single event (St. Louis et al., 2005; Hall et al., 2005). At present, the understanding on the sources of $\mathrm{MeHg}$ in atmosphere or precipitation is very limited (Hammerschmidt et al., 2007). Previous studies speculated that $\mathrm{MeHg}$ in precipitation could originate from the capture of $\mathrm{MeHg}$ from atmosphere as well as the oxidation of dimethyl mercury to $\mathrm{MeHg}$ (Brosset and Lord, 1995). However, the extents of both processes are typically confined within the atmosphere. Recently, Hammerschmidt et al. (2007) found that $\mathrm{MeHg}$ in precipitation could be derived from the aqueous phase methylation through a reaction between labile $\mathrm{Hg}(\mathrm{II})$ complexes and (an) unknown methylating agent(s).

Deposition is one of the most important steps of $\mathrm{Hg}$ biogeochemical cycle in the atmosphere. Numerous studies suggested that atmospheric deposition is the primary source of $\mathrm{Hg}$ to terrestrial and aquatic ecosystems (Lombard et al., 2011), such as Great Lakes (Fitzgerald et al., 1991; Landis and Keeler, 2002), remote inland lakes (Sorensen et al., 
1990) and forested catchments (Munthe et al., 1995a). Some other studies considered atmospheric deposition of $\mathrm{MeHg}$ to be a minor contributor to the aquatic ecosystem (Mason et al., 2000), while some investigators argued that wet deposition could be an important source of $\mathrm{MeHg}$ for certain ecosystems (Munthe et al., 1995b; Rolfhus et al., 2003), such as upland watershed at the ELA (St. Louis et al., 1994).

Investigating the distributions of $\mathrm{Hg}$ deposition is of significant importance to the understanding of the fate of $\mathrm{Hg}$ in the environment. Therefore, numerous long-term monitoring stations have already been set up worldwide, like the Mercury Deposition Network (MDN, with more than 100 active stations by now) (National Atmospheric Deposition Program, 2007). Environment Canada also operated Canadian Atmospheric Mercury Measurement Network (CAMNet) which had 11 sampling sites in 1994 (CAMNet, 2006). Only a few monitoring studies of $\mathrm{Hg}$ deposition have been carried out at remote and suburban locations in China. Guo et al. (2008) and Fu et al. (2010b) reported that the annual mean $\mathrm{Hg}$ concentrations in precipitation were higher in some semi-remote and remote Chinese areas, when compared to some areas in other countries (Guentzel et al., 2001; Sakata and Marumoto, 2005). Although China is recognised as one of the biggest emitters of atmospheric $\mathrm{Hg}$ (Zhang and Wong, 2007; Jiang et al., 2006), there lacks long-term Hg research networks capable to depict temporal and spatial distribution of $\mathrm{Hg}$ in precipitation. Therefore, it is very urgent to conduct long-term continuous measurements of $\mathrm{Hg}$ concentrations in precipitation and its deposition fluxes in China.

Anthropogenic $\mathrm{Hg}$ emissions in China show a clear pattern in regional distribution (Wu et al., 2007), while the southwestern China is considered as a seriously affected area (Streets et al., 2005). Chongqing, locates in southwestern China, is regarded as a traditional industrial city. With heavy industry as the main player in the local economy, it has a large demand on energy, about $70 \%$ of which is derived from coal in which the average mercury concentration is $0.32 \mathrm{mg} \mathrm{kg}^{-1}$ (Wang et al., 2006). Previous studies showed that a large amount of $\mathrm{Hg}$ emitted into the atmosphere was associated with coal combustion (Wang et al., 1999). The industries locate in the core urban areas are the major sources of $\mathrm{Hg}$ pollution to ambient air (Yang et al., 2009). Chongqing, with a complex terrain, is surrounded by hills and mountains, where the average wind speed is as slow as $0.95 \mathrm{~m} \mathrm{~s}^{-1}$ (Li et al., 2010). Thus, the area is prone to high atmospheric stability and radiation, inhibiting the spreading of mercury to the ambient. In addition, the urban heat island effect also decreases the speed of air flow, resulting in higher atmospheric $\mathrm{Hg}$ level in core urban area. It was reported that the annual mean concentration of $\mathrm{Hg}^{0}$ in main districts of Chongqing $\left(6.74 \pm 0.37 \mathrm{ng} \mathrm{m}^{-3}\right)$ was three folds higher than the global background level (Yang et al., 2009). With the process of precipitation, the increased $\mathrm{Hg}$ which entered the terrestrial ecosystem could endanger the living creature. In ad- dition, acid deposition is also more serious in Chongqing, which results in high washout ratio and $\mathrm{MeHg}$ formation.

To investigate the spatial and temporal distribution patterns of $\mathrm{Hg}$ in precipitation in Chongqing, $\mathrm{THg}$ and $\mathrm{MeHg}$ concentrations in precipitation at three typical sites (including the downtown, suburban and controlled sites in the city) were determined from July 2010 to June 2011. The objectives of this study were: (1) to quantify the concentrations of THg and $\mathrm{MeHg}$ in core urban areas in Chongqing; (2) to provide fundamental data for $\mathrm{Hg}$ cycling on a global scale.

\section{Materials and methods}

\subsection{Study area and sampling sites}

The Chongqing Municipality locates in the upstream of the Yangtze River with a population of 33030000 in 2010. Its topography is characterised by valley, hills and mountains; the elevation ranges from 145 to $2797 \mathrm{~m}$ above sea level. In addition, it has a typical subtropical humid monsoon climate with an annually average temperature of $18.8^{\circ}$ and average annual rainfall of $1200 \mathrm{~mm}$ (Yang et al., 2009).

Three sampling sites were selected for monitoring precipitation in Chongqing city, which were located in the downtown, suburban and controlled sites in the city, respectively. Detailed descriptions of the three stations are provided in Table 1 . In addition, the locations of the sampling points are illustrated in Fig. 1.

\subsection{Sampling methods}

The rain samples were collected by automatic precipitation sampler (APS-3A, Changsha Xianglan Scientific Instruments Co., Hunan, China) which was situated on unshadowed building roof at each sampling site. The sampler consisted of one tipping-bucket rain gauge, one moisture sensor, one automatic cover, one funnel, eight sampling borosilicate bottles, eight Teflon tubes connecting the funnel to the sampling bottles and one portable fridge for cold storage $\left(4^{\circ}\right)$ of the rain samples. The moisture sensor would activate the electric pathway allowing automatic removal of the funnel cover during the rain event. Each precipitation event was sampled from each site during the period from July 2010 to June 2011. In a precipitation event, we defined the period of rain as since the triggering of moisture sensor to the next day 09:00 a.m. Then the sampling borosilicate bottle was altered automatically for the next precipitation event.

The water samples were divided into two bottles in the sampling field. One bottle was used for the measurement of $\mathrm{pH}$ and the concentrations of major anions. The other bottle was further separated into two samples, one filtered through $0.45 \mu \mathrm{m}$ microfilters (Millipore, USA) for analyses of dissolved total mercury $(\mathrm{DHg})$ and dissolved methylmercury (DMeHg); the other was unfiltered for analyses of $\mathrm{THg}$ and total methylmercury $(\mathrm{MeHg})$. All the samples analysed for 
Table 1. Description of sampling sites in core urban areas, Chongqing, China.

\begin{tabular}{lll}
\hline Site & Type & Descript \\
\hline Nanan District (NA) & Downtown & A crowed place with lots of markets and high population density (2294 people per square kilometre) \\
Beibei District (BB) & Suburban site & A residential area with good vegetation cover, population density (843 people per square kilometre) \\
Jinyun Mountain (JY) & Controlled site & Near rural regions, covered by extensive forest with little human activities \\
\hline
\end{tabular}
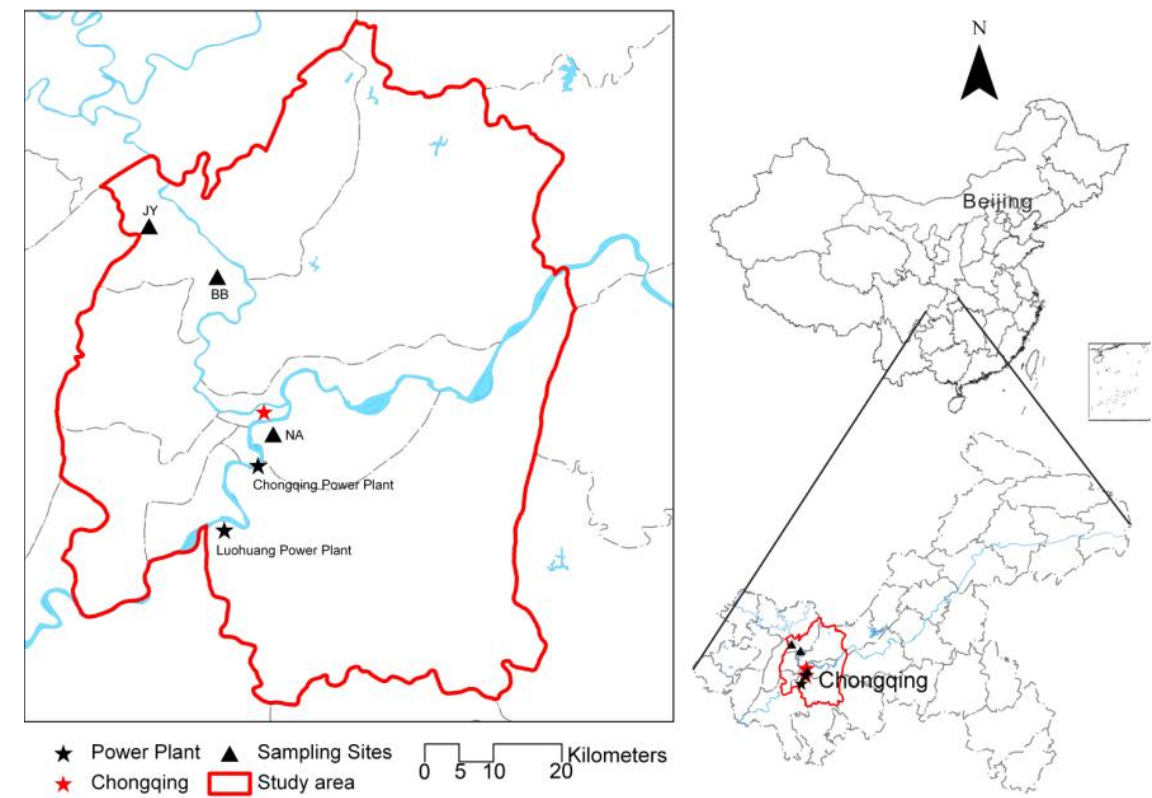

Fig. 1. The locations of study area and sampling sites.

species of $\mathrm{Hg}$ were acidified to $5 \%(v / v)$ using concentrated hydrochloric acid $(\mathrm{HCl})$. The rain samples were transported to the lab on ice, and then stored in a refrigerator at $+4^{\circ}$ in the dark until analysis.

The water samples were transferred from sampler to acid cleaned borosilicate glass bottles. These bottles were initially soaked in $10 \%(v / v) \mathrm{HNO}_{3}$ for at least $48 \mathrm{~h}$, followed by rinsing with ultra-pure water $\left(18.2 \mathrm{M} \Omega \mathrm{cm}^{-1}\right)$, and baked for one hour in a muffle furnace at $500^{\circ}$. Finally, they were doubly bagged and stored in wooden boxes until use. All operations were performed in accordance with ultraclean sample handing protocols.

\subsection{Sample analysis}

For THg and DHg determinations, the samples were analysed (following the EPA Method 1631) by Cold Vapor Atomic Fluorescence Spectrometry (CVAFS, Brooks Rand model III, Brooks Rand Laboratories, Seattle, WA) after oxidation, reduction and trap (US EPA, 2002). Complying with the EPA Method 1630, samples for $\mathrm{MeHg}$ and DMeHg determinations went through distillation, ethylation and gas chromatographic (GC) separation before CVAFS analyses (US EPA, 2001).
The major anions: nitrate $\left(\mathrm{NO}_{3}^{-}\right)$, nitrite $\left(\mathrm{NO}_{2}^{-}\right)$, sulfate $\left(\mathrm{SO}_{4}^{2-}\right)$, chloride $\left(\mathrm{Cl}^{-}\right)$, phosphate $\left(\mathrm{PO}_{4}^{3-}\right)$ in precipitation were measured using Dionex DX-120 Ion Chromatograph according to EPA method 300.0 (US EPA, 1993). Phosphate and nitrate concentrations were often below detection limits $\left(0.03 \mathrm{mg} \mathrm{l}^{-1} \mathrm{PO}_{4}^{3-}\right.$ and $\left.0.02 \mathrm{mg} \mathrm{l}^{-1} \mathrm{NO}_{2}^{-}\right)$, thus, not included in our discussion. After transporting the samples to lab, $\mathrm{pH}$ was immediately measured.

\subsection{Quality control and statistical analysis}

Quality controls for THg and MeHg determinations included method blank, blank spikes, duplicates and matrix spikes. The method detection limits $(3 \times \sigma)$ of $\mathrm{THg}$ and $\mathrm{MeHg}$ were $0.02 \mathrm{ng}^{-1}$ and $0.01 \mathrm{ngl}^{-1}$. The method blank was lower than the detection limits in all cases. The average relative standard deviation for the duplicate analyses of $\mathrm{THg}$ and $\mathrm{MeHg}$ were $5.2 \%$ and $5.4 \%$, respectively. Recoveries for matrix spikes ranged from 95 to $110 \%$ for $\mathrm{THg}, 85$ to $108 \%$ for $\mathrm{MeHg}$. The equipment blanks of automatic precipitation sampler for THg and MeHg were $0.04 \mathrm{ng}^{-1}$ and $0.02 \mathrm{ng}^{-1}$, respectively. 
Table 2. Comparison of $\mathrm{THg}$ and $\mathrm{MeHg}$ concentration in precipitation measured in Core urban area, Chongqing, China and those at other sites.

\begin{tabular}{|c|c|c|c|c|c|c|}
\hline & \multirow[t]{2}{*}{ Rainfall (mm) } & \multicolumn{2}{|c|}{ Concentration $\left(\mathrm{ng} 1^{-1}\right)$} & \multirow[t]{2}{*}{ Time } & \multirow[t]{2}{*}{ Classification } & \multirow[t]{2}{*}{ Reference } \\
\hline & & $\mathrm{THg}$ & $\mathrm{MeHg}$ & & & \\
\hline Main urban area, Chongqing, China & 921 & $30.67(5.81-157.58)$ & $0.31(0.04-1.94)$ & Jul 2010 to Jun 2011 & Urban & This study \\
\hline Wujiang, Guizhou, China & 963 & $36.0(7.5-149.1)^{\mathrm{a}}$ & $0.19(0.08-0.82)^{\mathrm{a}}$ & Jan to Dec 2006 & Semi-remote & Guo et al. (2008) \\
\hline Mt.Leigong, Guizhou, China & 1533 & $4(1.2-30.8)$ & $0.04(<$ detection level to 0.15$)$ & May 2008 to May 2009 & Remote & Fu et al. (2010a) \\
\hline Mt.Gongga, Sichuan, China & 1818 & $14.3 \pm 7.7$ & $0.16 \pm 0.08$ & May 2005 to Apr 2007 & & Fu et al. (2010b) \\
\hline Mt.Changbai, Jilin, China & & $11.5-15.9$ & & Aug 2005 to Jul 2006 & Remote & Wan et al. (2009) \\
\hline Caryville, Tennessee, USA & $1410 \pm 100$ & $10 \pm 1$ & & $1995-1996$ & Town & Guentzel et al. (2001) \\
\hline Underhill, Veront, USA & $1091^{\mathrm{b}}$ & $7.8-10.5^{\mathrm{c}}$ & & 1993-2004 & Remote & Keeler et al. (2005) \\
\hline Newcomb, New York, USA & & $4.9(0.2-28.5)$ & & Dec 2004 to Dec 2006 & Remote & Choi (2008) \\
\hline Great Lake Region & & $13.5(10-60)$ & $0.097(0.01-0.85)$ & May 1997 to Dec 2003 & & Hall et al. (2005) \\
\hline ELA, Northwestern Ontario, Canda & 835.8 & $4.04(0.95-9.31)$ & $0.052(0.010-0.179)$ & $1992-1993$ & Remote & St. Louis et al. (1995) \\
\hline $\begin{array}{l}\text { Coweeta Hydrologic Laboratory, } \\
\text { North Carolin, USA }\end{array}$ & 139.7 & $5.75-25$ & $<0.025-0.16$ & 11 Jun-14 Jul 1994 & Remote & Allan et al. (1998) \\
\hline
\end{tabular}

a Precipitation Hg concentrations in Wujaing, China probably overestimate the "real" levels of precipitations semi-rural areas of Guizhou province for its measurements impacted by dry depositions.

b Mean rainfall for $11 \mathrm{yr}$.

c The range of annual VMW concentration for $11 \mathrm{yr}$.

Statistical analyses were performed using SPSS 13.0 software. The differences among sites as well as seasons were tested by the analysis of variation (ANOVA). 0.05 was used as the level of significance for these analyses.

Volume-weighted (VMW) mean concentration is calculated by the following formula (Acid Deposition Monitoring Network in East Asia, 2012):

$\mathrm{VMW}=\left(X_{1} \times V_{1}+X_{2} \times V_{2}+\cdots+X_{\mathrm{t}} \times V_{\mathrm{t}}\right) /$

$\left(V_{1}+V_{2}+\cdots+V_{\mathrm{t}}\right)=\sum\left(X_{\mathrm{t}} \times V_{\mathrm{t}}\right) / \sum V_{\mathrm{t}}$

where, $X_{\mathrm{t}}$ is the ion concentration of each precipitation event $\left(\mathrm{ng} \mathrm{l}^{-1}\right), V_{\mathrm{t}}$ is the rainfall $(\mathrm{mm})$.

\section{Results}

\subsection{Total mercury in precipitation}

Concentrations of $\mathrm{THg}$ in precipitation at the three sites from July 2010 to June 2011 ranged from 5.81 to $157.58 \mathrm{ng}^{-1}$, with an annual volume-weighted (VMW) mean concentration of $30.67 \mathrm{ng} \mathrm{l}^{-1}(n=258)$ (Table 2). Table 2 also shows a comparison of THg concentrations in some other sites in China or other countries. The mean concentration of $\mathrm{THg}$ in core urban area, Chongqing was close to that reported in Wujiang River Basin, Guizhou, China (Guo et al., 2008), but significantly higher than those reported in some remote areas such as Mt. Leigong, Guizhou, China (Fu et al., 2010a), Mt. Gongga, Sichuan, China (Fu et al., 2010b), Mt. Changbai, Jilin, China (Wan et al., 2009), Underhill, Veront, USA (Keeler et al., 2005) and Great Lake Region (Hall et al., 2005).

Additionally, most of the mercury in precipitation was associated with particulates, which accounted for $8.3 \%$ to $92.7 \%$ (mean $63.3 \%$ ) of total mercury, suggesting that $\mathrm{PHg}$ was dominant among the different mercury species. The high correlation ( $r=0.968, p=0.000)$ was also observed between $\mathrm{PHg}$ and $\mathrm{THg}$ concentrations indicating that the $\mathrm{THg}$ concentration in precipitation may be influenced by the $\mathrm{PHg}$ concentration.

In order to evaluate the spatial and temporal distribution of THg, all the measurements were grouped by seasons and sites (Fig. 2). The seasonal variations of THg in precipitation were obvious with higher mean $\mathrm{THg}$ concentrations in winter (December, January, and February) at all sampling sites.

This finding was similar to the seasonal variations of THg in precipitation in Wujiang River Basin, Guizhou, China; but in contrast to the observations in North America (Landis and Keeler, 2002), Adirondacks (Choi et al., 2008) and Great Lakes region (Hall et al., 2005), which found increased THg concentration during summer months.

A spatial trend of decreasing $\mathrm{THg}$ concentrations in precipitation was observed from the downtown (NA) to suburban site (BB) and then to the controlled site (JY) in the city. Anthropogenic influences (discuss in Sect. 3.5) and urban heat-island effect can be considered as possible explanations for this trend. THg concentrations at the downtown (NA) (VMW mean concentration $35.95 \mathrm{ng}^{-1}$ ) is statistically significantly higher than that at suburb $(\mathrm{BB})(p=0.018)$ and controlled site (JY) $(p=0.000)$, while no significant difference between BB and JY was observed $(p=0.060)$. In order to further understand the spatial variations of $\mathrm{THg}$ concentrations in precipitation, all the samples collected at three sites were divided into six groups based on their initial concentrations: $<10 \mathrm{ng} \mathrm{l}^{-1}, 10-20 \mathrm{ng} \mathrm{l}^{-1}, 20-40 \mathrm{ng} \mathrm{l}^{-1}, 40-60 \mathrm{ng} \mathrm{l}^{-1}$, $60-80 \mathrm{ng} \mathrm{l}^{-1},>80 \mathrm{ng} \mathrm{l}^{-1}$ (Fig. 3). The majority of all events at NA, BB, and JY were in the range of $20-40 \mathrm{ng} \mathrm{l}^{-1}$. More than $10 \%$ of all events at NA had THg concentration exceeding $80 \mathrm{ng}^{-1}$, all observed in winter months (December, January); contrarily, less than $5 \%$ of events at BB (three events) and JY (three events) had concentrations that high. 


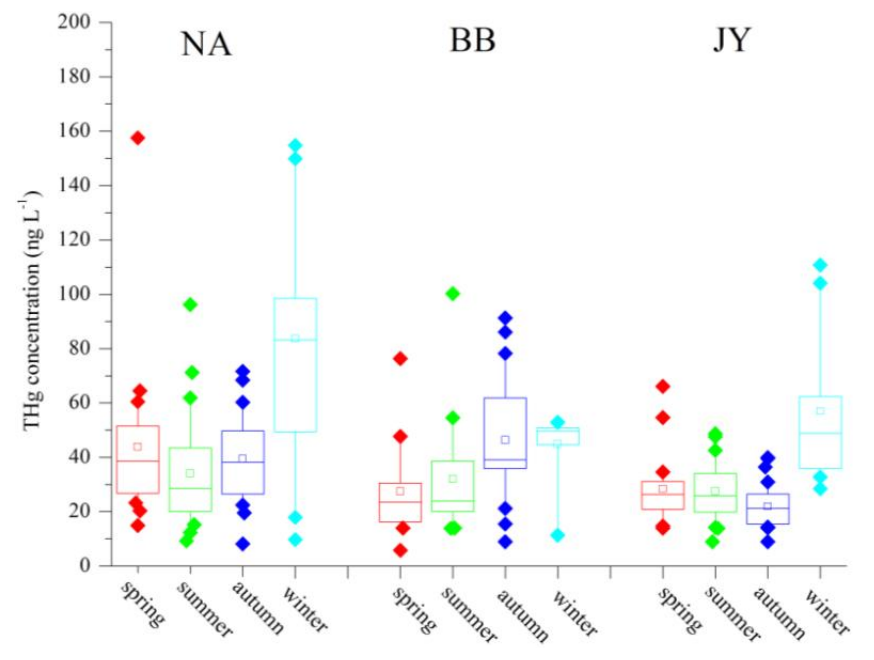

Fig. 2. THg concentrations in all precipitation samples at three sampling sites over time. Box plot showing median (solid line), mean (small square), 25th and 75th percentiles (box boundary), 10th and 90th percentiles (whiskers).

At all three sites, events with $\mathrm{THg}$ concentrations less than $10 \mathrm{ng}^{-1}$ were the rarest.

\subsection{Methyl mercury in precipitation}

From Table 2, measured $\mathrm{MeHg}$ concentrations at the three sites were ranged in $0.04-1.94 \mathrm{ng} \mathrm{l}^{-1}$, the annual VMW mean $\mathrm{MeHg}$ concentration was $0.31 \mathrm{ng}^{-1}$. When compared to other researches (Table 2), it was much higher than the levels reported in rural area in Wujiang Basin and Mt.Leigong, Guizhou, China (Guo et al., 2008; Fu et al., 2010a), Great lake regions (Hall et al., 2005) and ELA, Canada (St. Louis et al., 1994). It was also determined that 6.2-91.9\% (mean $40.5 \%$ ) of the measured $\mathrm{MeHg}$ was associated with particles and the correlation between $\mathrm{MeHg}$ and $\mathrm{PMeHg}$ concentrations was strong $(r=0.527, p=0.005)$.

Percentage of $\mathrm{MeHg}$ in $\mathrm{THg}(\% \mathrm{MeHg})$ in precipitation was $0.1-6.9 \%$ (mean $1.3 \%$ ), $0.1-1.8 \%$ (mean $0.7 \%$ ), and $0.2-7.6 \%$ (mean $1.9 \%$ ) in NA, BB, JY, respectively. Figure 4 shows the $\% \mathrm{MeHg}$ in all the samples at the three sites from July 2010 to June 2011 . The majority of $\% \mathrm{MeHg}$ was around $1.0 \%$ which was comparable to those reported in northern Wisconsin (mean 1.3\%) (Lamborg et al., 1995) and Great lakes region (most of \% MeHg below $1 \%$ ) (Hall et al., 2005); but was higher than that reported in Wujiang Basin, China (mean $0.7 \%$ ) (Guo et al., 2008). However, when compared with $\% \mathrm{MeHg}$ in estuarine and marine waters (less than $5 \%$ ) or freshwater lakes and rivers (up to 30\%) (Coquery et al., 1997; Leermakers et al., 1996; Mason and Sullivan, 1999; Meili, 1997), it showed a lower $\mathrm{MeHg}$ production in precipitation. Higher \% MeHg was discovered from September 2010 to November 2010, due to increased $\mathrm{MeHg}$ and decreased $\mathrm{THg}$ concentrations in autumn. There were only a small num-
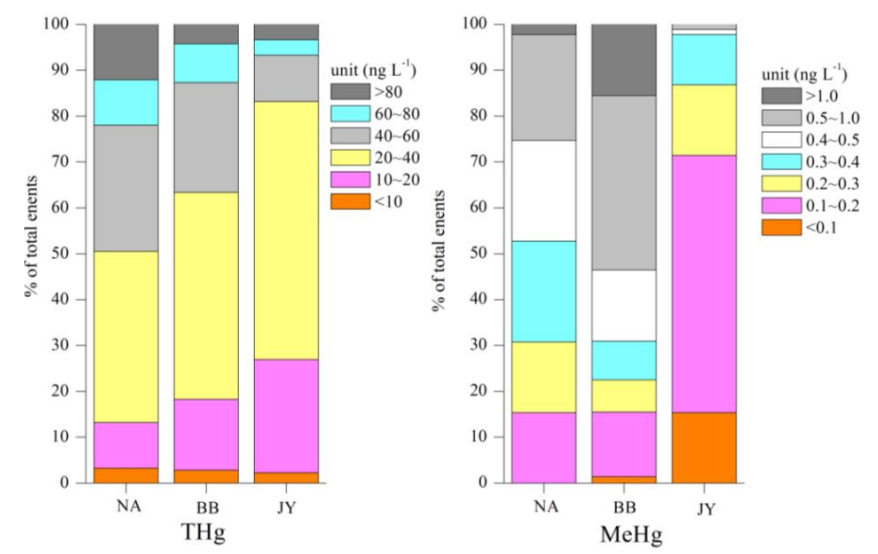

Fig. 3. The frequency distribution for $\mathrm{THg}$ and $\mathrm{MeHg}$ concentrations at three sites during one year period.

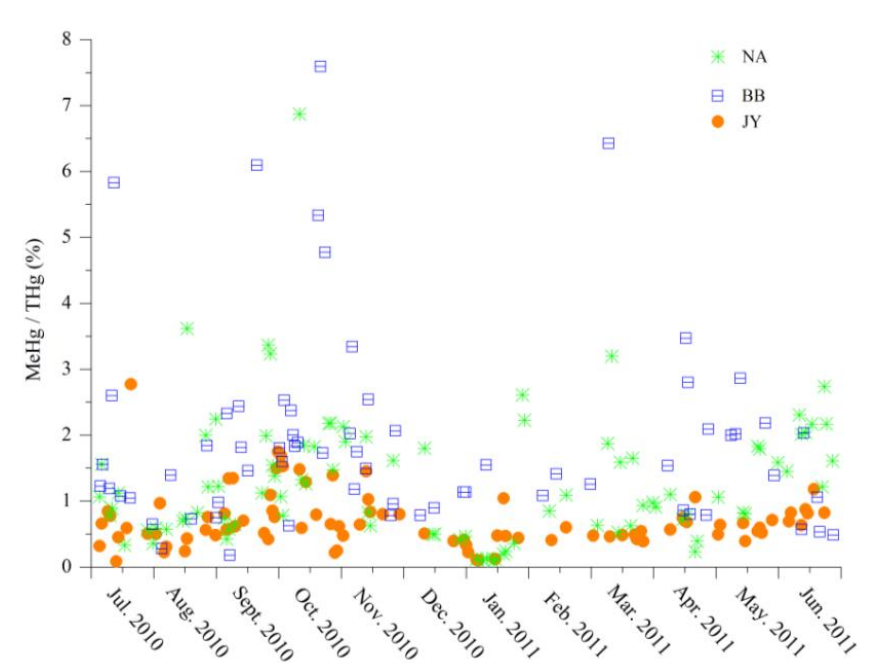

Fig. 4. The percent of $\mathrm{THg}$ present as $\mathrm{MeHg}$ in all precipitation events at 3 sites.

ber of events with $\% \mathrm{MeHg}$ beyond $4 \%$, most of them appeared at BB except one at NA site (in October 2010).

There were significant seasonal variations of mean $\mathrm{MeHg}$ concentration. The highest arithmetic mean MeHg concentration occurred in autumn months (VMW mean concentration $0.45 \mathrm{ng}^{-1}$ ) (Fig. 5), which was significantly higher than those sampled in other seasons (spring VMW $0.28 \mathrm{ng}^{-1}$, $p=0.000$; summer VMW $0.27 \mathrm{ngl}^{-1}, p=0.000$; winter VMW $\left.0.38 \mathrm{ng} \mathrm{l}^{-1}, p=0.001\right)$. This finding about the temporal distribution of MeHg in precipitation is not consistent with observations in many regions which showed increased $\mathrm{MeHg}$ concentration during winter months (Guo et al., 2008; Bloom et al., 2004). In spring, summer and winter, $\mathrm{MgHg}$ concentrations did not show clear seasonal trend, especially at JY sites the $\mathrm{MeHg}$ concentrations in those three seasons were similar. The spatial variation in $\mathrm{MeHg}$ concentrations was obvious, the highest mean value $\left(1.94 \mathrm{ng}^{-1}\right)$ 
Table 3. The consumption of total energy and coal (10000 tons of Standard Coal Equivalent) and the percentage of coal consumption to total energy consumption from 2001 to 2010 in Chongqing.

\begin{tabular}{|c|c|c|c|c|c|c|c|c|c|c|}
\hline year & 2001 & 2002 & 2003 & 2004 & 2005 & 2006 & 2007 & 2008 & 2009 & 2010 \\
\hline coal consumption & 1700.4 & 1929.9 & 2206.4 & 2505.1 & 3151.7 & 3381.9 & 3832.3 & 4049.0 & 4499.8 & 4857.6 \\
\hline total consumption of energy & 2573.7 & 2823.1 & 3137.9 & 3668.4 & 4464.6 & 4881.6 & 5512.4 & 5895.1 & 6431.6 & 7117.4 \\
\hline $\operatorname{coal} \%$ & $66.1 \%$ & $68.4 \%$ & $70.3 \%$ & $68.3 \%$ & $70.6 \%$ & $69.3 \%$ & $69.5 \%$ & $68.7 \%$ & $70.0 \%$ & $68.3 \%$ \\
\hline
\end{tabular}

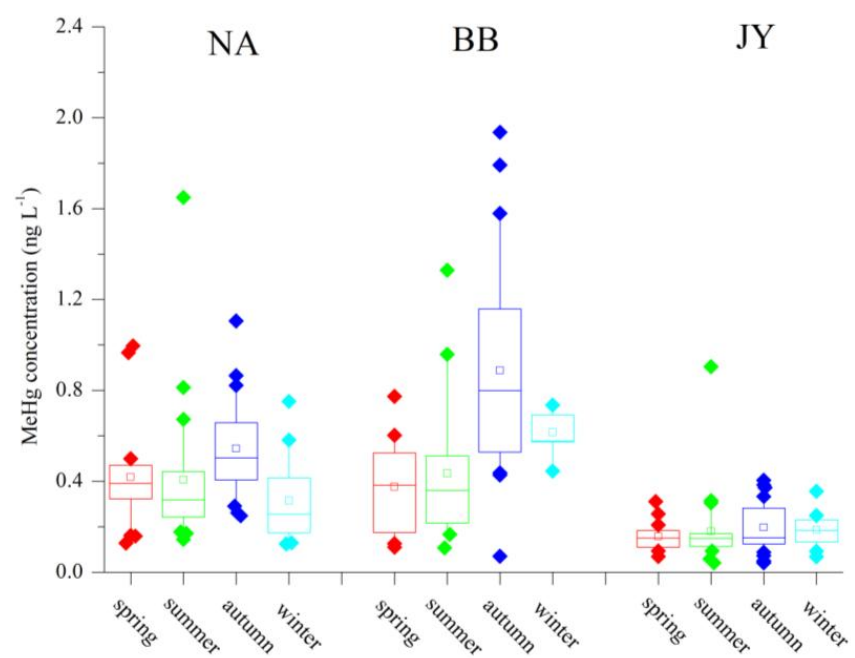

Fig. 5. MeHg concentrations in all precipitation samples at three sampling sites over time.

was observed at BB (suburb) while the lowest $\left(0.04 \mathrm{ng} \mathrm{l}^{-1}\right)$ was observed at JY (control site).

The yearly frequency of events with $\mathrm{MeHg}$ concentrations among $0.1-0.2 \mathrm{ngl}^{-1}, 0.2-0.3 \mathrm{ngl}^{-1}, 0.3-0.4 \mathrm{ngl}^{-1}$, $0.4-0.5 \mathrm{ng}^{-1}$, and $0.5-1.0 \mathrm{ng}^{-1}$ at NA is similar (Fig. 3). Events with $\mathrm{MeHg}$ concentrations under $0.1 \mathrm{ngl}^{-1}$ were recorded at JY, accounted for about $15 \%$ of all events. At JY, events with lower $\mathrm{MeHg}$ concentration were more frequent, about $60 \%$ of all fall into the $0.1-0.2 \mathrm{ng}^{-1}$ range. At least $15 \%$ of all events at $\mathrm{BB}$ had $\mathrm{MeHg}$ concentrations exceeding $1.0 \mathrm{ng} \mathrm{l}^{-1}$ which was not observed at JY.

\section{Discussion}

\subsection{Relationship between mercury concentrations in precipitation and rain depth}

$\mathrm{THg}, \mathrm{MeHg}$ concentrations as well as the corresponding precipitation amount of every rain event at the three sites were shown in Fig. 6. Our results show that the $\mathrm{THg}$ and $\mathrm{MeHg}$ concentrations varied with rain amount. Significant negative correlations between THg and rain amount $(r=-0.176$, $p=0.005)$, as well as $\mathrm{MeHg}$ and the rain amount $(r=$ $-0.151, p=0.016)$ were also observed. In our research, lower rain amount in winter $(47.8 \mathrm{~mm}$, about one-tenth of that in summer) may be one possible reason for the highest $\mathrm{THg}$ concentration.

Frequent plum rains (continuous light rain) in autumn may explain the highest $\mathrm{MeHg}$ concentration. Light rain tends to have higher $\mathrm{MeHg}$ concentrations than does heavy rain, considering the similar amount of total $\mathrm{MeHg}$ sharing in different study sites. Statistically significant difference in $\mathrm{MeHg}$ was observed between spring and autumn $(p=0.520)$, although the precipitation amount was similar in spring $(263.5 \mathrm{~mm}, 20$ events) and autumn $(207.1 \mathrm{~mm}, 28$ events).

We grouped the measurements at the three sites according to the rainfall (China Meteorological Administration): light rain $0-10 \mathrm{~mm} \mathrm{~d}^{-1}$; moderate rain $10-25 \mathrm{~mm} \mathrm{~d}^{-1}$ and heavy rain $25-50 \mathrm{~mm} \mathrm{~d}^{-1}$ (Fig. 7). Torrential rains $\left(50-100 \mathrm{~mm} \mathrm{~d}^{-1}\right)$ and downpours $\left(>100 \mathrm{~mm} \mathrm{~d}^{-1}\right)$ were not taken into our consideration due to low frequencies. Figure 7 shows that lighter rain events exhibit higher THg and $\mathrm{MeHg}$ concentrations. THg concentrations measured in rainfalls less than $2 \mathrm{~mm}$ were significantly higher than those from heavier rains $(2-5 \mathrm{~mm}, p=0.001 ; 5-10 \mathrm{~mm}, p=0.000 ; 10$ $25 \mathrm{~mm}, p=0.000$; $25-50 \mathrm{~mm}, p=0.000) .25-50 \mathrm{~mm}$ rainfall showed statistically significant difference in $\mathrm{THg}$ concentration when compared to $<2 \mathrm{~mm}(p=0.000)$ and $2-$ $5 \mathrm{~mm}$ rainfall $(p=0.042)$. However, there was no significant difference observed when compared to $5-10 \mathrm{~mm}(p=0.277)$ and $10-25 \mathrm{~mm}(p=0.188)$ rainfall. These results support the perspective that atmospheric mercury is effectively scavenged during the early part of the rain event (Guo et al., 2008; Hall et al., 2005). As described above, it is likely that the PHg in precipitation accounted for about $63.3 \%$ of $\mathrm{THg}$ in our research, being consistent with that the scavenging of PHg by precipitation contributed significantly to mercury wet deposition at urban site (Sakata and Marumoto, 2005).

In addition, our research also preliminarily indicates that $0-5 \mathrm{~mm}$ rainfall plays a dominant role in scavenging atmospheric $\mathrm{Hg}$ and $5 \mathrm{~mm}$ may be a threshold value for the biggest wash-out capability to $\mathrm{Hg}$. The part of rain exceeding $5 \mathrm{~mm}$ may play a dilution role in term of concentration, instead of washing out.

However, no statistically significant difference was observed between rainfall and $\mathrm{MeHg}$ concentrations. 


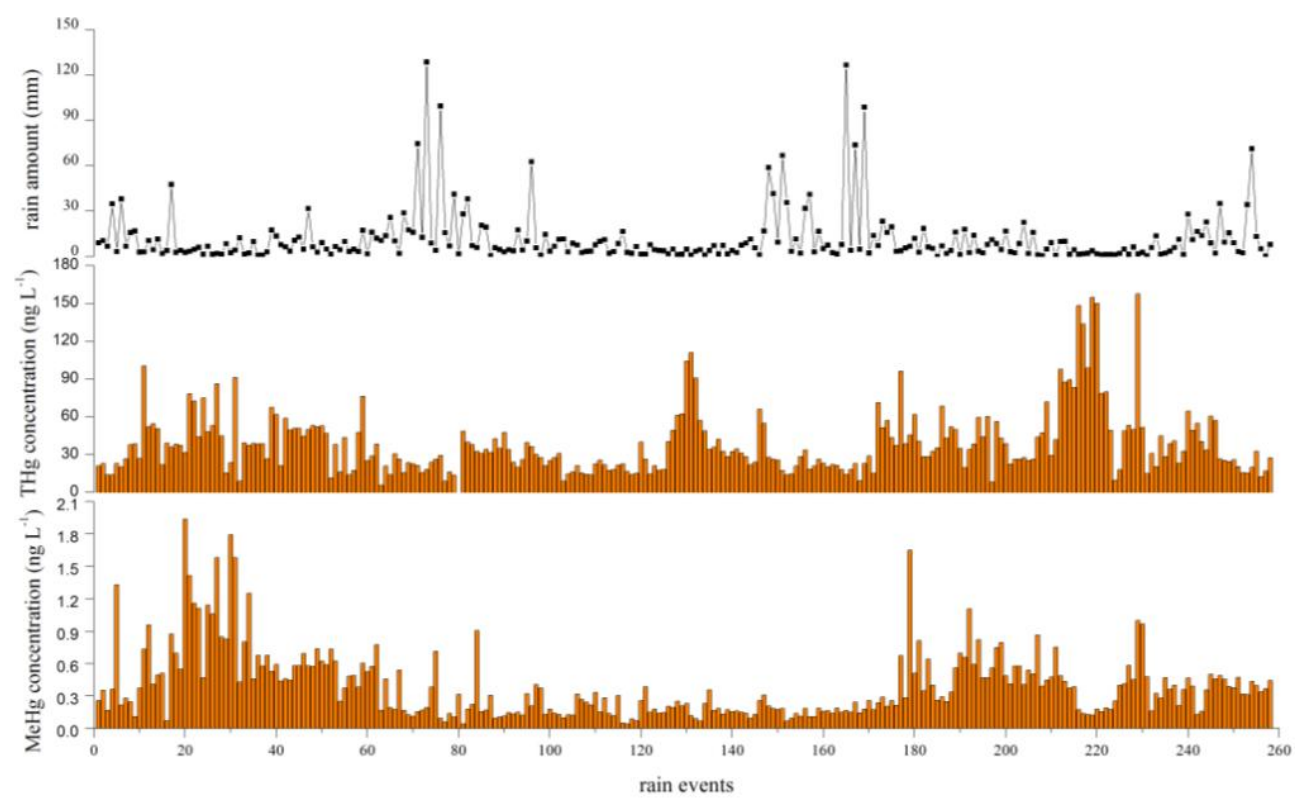

Fig. 6. The relationship between $\mathrm{THg}$ and $\mathrm{MeHg}$ concentrations with rain amount.

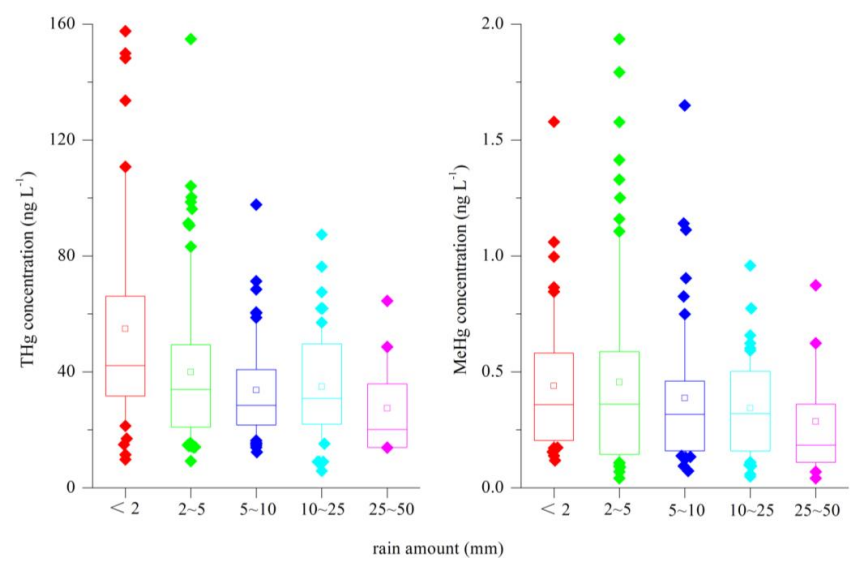

Fig. 7. $\mathrm{THg}$ and $\mathrm{MeHg}$ concentrations in precipitation collected from three sampling sites grouped together according to different rain amount.

\subsection{Anthropogenic influence on mercury distribution in precipitation}

In order to investigate the anthropogenic contributions to precipitative $\mathrm{Hg}$, we examined the correlations between $\mathrm{THg}$ and major anions in precipitation. It is interesting that a highly significant correlation was observed between $\mathrm{THg}$ and $\mathrm{SO}_{4}^{2-}(r=0.306, p=0.000)$, and between $\mathrm{THg}$ and $\mathrm{NO}_{3}^{-}(r=0.314, p=0.000)$ concentrations in precipitation. $\mathrm{SO}_{4}^{2-}$ and $\mathrm{NO}_{3}^{-}$in precipitation mainly come from the washout of $\mathrm{SO}_{2}, \mathrm{NO}_{\mathrm{x}}$ in atmosphere, which are indicators for anthropogenic influences (Mao et al., 2008).
$\mathrm{SO}_{2}$ is emitted primarily from the combustion of coal. Coal combustion emission of $\mathrm{Hg}$ (about $5 \mathrm{t} \mathrm{yr}^{-1}$ ) contributes to about $57 \%$ of total anthropogenic emissions in Chongqing (Wang et al., 2006). In recent $10 \mathrm{yr}$, with the industrial developments in Chongqing, the coal consumption increased from $17.0 \times 10^{6}$ tons of Standard Coal Equivalent (SCE) in 2001 to $48.6 \times 10^{6}$ tons in 2011 (Chongqing Statistics Yearbook, 2011). In addition, sulfur-rich coal makes a large proportion in the coal consumption in Chongqing, which unleashes increasing $\mathrm{SO}_{2}$ into the atmosphere (as shown in Fig. 8, $\mathrm{SO}_{4}^{2-}$ accounts for about $75 \%$ in all anions), and results in serious acid rain, which affects biogeochemical behaviours of $\mathrm{Hg}$, leading to a high washout ratio and formation of MeHg (Branfireun et al., 1999; Wong et al., 2006). In our research, the $\mathrm{pH}$ ranged from 2.88 to 7.27 , with an acid rain $(\mathrm{pH}<5.6)$ frequency up to $80 \%$. However, there was no significant correlation between $\mathrm{pH}$ and $\mathrm{THg} / \mathrm{MeHg}$ concentrations ( $p=0.587 ; p=0.530)$. Thereafter, we preliminarily presume that the coal combustion is a main source for mercury wet deposition in Chongqing. Similarly, in Eastern Ohio, USA (Keeler et al., 2006) the dominant contributor to mercury wet deposition was found to be coal combustion $(\sim 70 \%)$. Thus, the increased coal combustion for domestic activities may also explain the high $\mathrm{THg}$ in precipitation in winter, besides the decreased rain amount (as discussed in Sect. 3.4). Guo et al. (2008) also pointed out that maximum $\mathrm{THg}$ concentrations in rain in winter may be related to coal burning in domestic activities.

$\mathrm{NO}_{\mathrm{x}}$ in atmosphere is emitted directly from the combustion of fossil fuels (such as coal) and transportation sources (Caffrey et al., 2010; Lynam and Keeler, 2006; Lombard et al., 2011). $\mathrm{NO}_{\mathrm{x}}$ exhibits peak concentrations in the morning, 


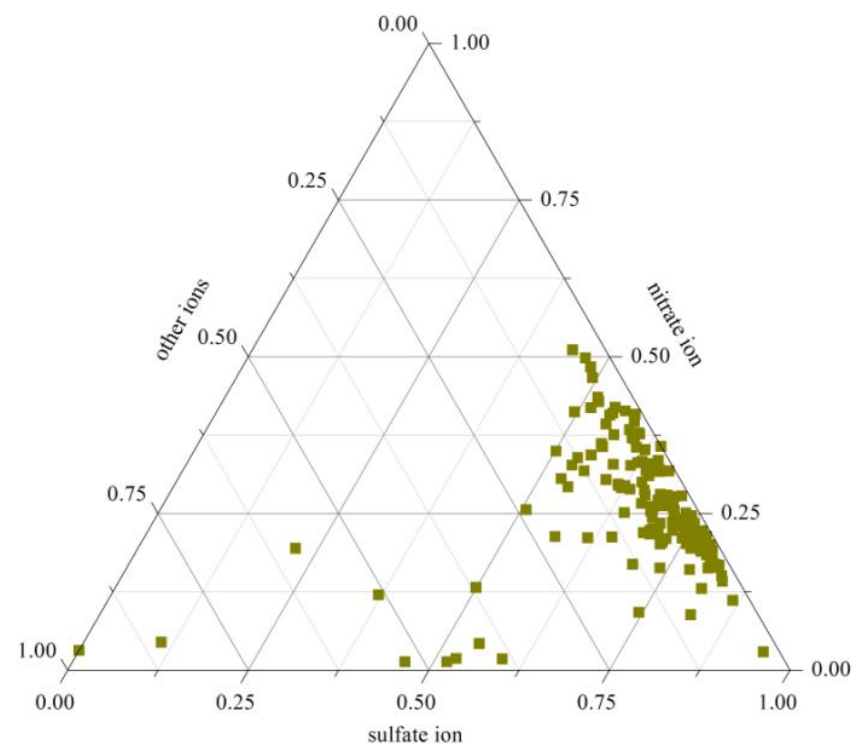

Fig. 8. The percent of main anions in precipitation.

typically associated with the morning commute emissions (Touma et al., 2006). In addition, transportation sources are considered as one of the contributors to atmospheric $\mathrm{Hg}$ in urban setting (Lyman and Gustin, 2008), and hourly averaged total gaseous mercury (TGM) concentrations were positively correlated with $\mathrm{NO}_{\mathrm{x}}\left(y=7.0 \mathrm{NO}_{\mathrm{x}}\right.$ in $\mathrm{ppm}+1.9, r^{2}=0.59$, $p<0.0001$ ) (Stamenkovic et al., 2007). Motor vehicles were one of the most important contributors to atmospheric $\mathrm{Hg}$ in Chongqing (Yang et al., 2009). In Chongqing, the number of civil motor vehicles had increased for 5.8 folds from 2000 to 2010 (Chongqing Statistics Yearbook, 2001-2011). $\mathrm{NO}_{3}^{-}$in precipitation made up $30 \%$ of all measured anions (Fig. 8). Hence, besides coal combustion, mobile transportation sources may also influence the $\mathrm{Hg}$ distribution patterns within the urban areas Chongqing.

Higher THg levels at NA site were probably owing to the dense population centres and heavy transportation. The sampling site in NA district is about $5 \mathrm{~km}$ away from the Chongqing thermal power plant and $15 \mathrm{~km}$ away from the Luohuang thermal power plant (Fig. 1) which will be removed from Chongqing core urban areas by the end of 2013. By generating abundant $\mathrm{Hg}$-containing particles (accounting for $62.6 \%$ of THg at NA site), these two power plants greatly influenced the precipitation $\mathrm{Hg}$ concentration. $\mathrm{PHg}$, generally depicted as regional and local pollutant for shorter atmospheric lifetime, deposits by wet and dry deposition within roughly 50 to 500 miles. Thus, $\mathrm{Hg}$ in precipitation at NA site might be related to $\mathrm{Hg}$ emissions in the surrounding area.

Unlike the NA site which locates in a relatively densely populated and crowded transport area, there is no major mercury emission source around the BB sampling site. Even though JY is relatively isolated from human activities (locates near rural areas and is generally characterised by ex- tensive forest cover), the results showed no significant difference between BB and JY sampling sites. Long range atmospheric transport of $\mathrm{Hg}$ from surrounding areas may be the predominant source for $\mathrm{Hg}$ in JY.

Increased atmospheric loadings of $\mathrm{Hg}$ could lead to enhanced MeHg in precipitation (Hammerschmidt et al., 2007). However, there was no significant correlation between concentrations of $\mathrm{MeHg}$ and $\mathrm{THg}$ in precipitation in our research, indicating that they may come from different sources, and not related with anthropogenic source. Sampling is ongoing at these sites, and further researches will be able to identify the long-term trend and sources of $\mathrm{MeHg}$ in atmosphere or precipitation.

\section{Conclusions}

From July 2010 to June 2011, THg and MeHg concentrations in precipitation were investigated in the core urban areas of Chongqing, a traditional industrial city consuming large amount of coal as the major fuel source (70\% of energy consumption). The annual mean $\mathrm{THg}$ and $\mathrm{MeHg}$ concentrations in precipitation were $30.67 \mathrm{ng} \mathrm{l}^{-1}$ and $0.31 \mathrm{ng} \mathrm{l}^{-1}$, respectively. The proportion of $\mathrm{MeHg}$ in $\mathrm{THg}$ ranged from $0.1 \%$ to $7.6 \%$ with a mean value of $1.3 \%$. An obvious seasonal variation of $\mathrm{THg}$ concentration was observed in precipitation, with highest value in winter and lowest in summer. This could attribute to the rain amount and the seasonal variations in anthropogenic emission sources, especially the coal combustion, a main source of mercury wet deposition in Chongqing. However, the highest $\mathrm{MeHg}$ value was observed in autumn. A geographic trend of decreasing THg concentrations in precipitation was also observed from the downtown to the suburb, and then to the controlled site in the city, which was related to regional and local emission sources and long range transport of $\mathrm{Hg}$. Furthermore, $5 \mathrm{~mm}$ rainfall may be a threshold for the full wash-out capability, rainfall exceeding $5 \mathrm{~mm}$ may have a diluting effect.

Acknowledgements. This work is financially supported by the Natural Science Foundation of China (40973079, 41173116) and Postgraduate Sci-tech Innovation Foundation of Southwest University (kb2010019). We thank Junjian Hu and Yaozu Guo for their assistance in the samples collections. We are very much grateful to Luo Peng and Lei Zhang at Winsor University, Canada, for their valuable suggestion and assistance to the revised manuscript.

Edited by: A. Dastoor 


\section{References}

Acid Deposition Monitoring Network in East Asis (EANET): http: //www.eanet.cc/product/, 2012.

Allan, C. J. and Heyes, A.: A preliminary assessment of wet deposition and episodic transport of total and methyl mercury from low order blue ridge watersheds, S.E. USA, Water Air Soil Poll., 105, 573-592, 1998.

Bloom, N. S., Moretto, L. M., Scopece, P., and Ugo, P.: Seasonal cycling of mercury and monomethyl mercury in the Venice Lagoon (Italy), Mar. Chem., 91, 85-99, 2004.

Branfireun, B. A., Roulet, N. T., Kelly, C. A., and Rudd, J. W. M.: In suit sulphate stimulation of mercury methylation in a boreal peatland: towards a link between acid rain and methylmercury contamination in remote environments, Global Biochem., 13, 743$750,1999$.

Brosset, C. and Lord, E.: Methylmercury in ambient air, Method of determination and some measurement results, Water Air Soil Poll., 82, 739-750, 1995.

Caffrey, J. M., Landing, W. M., Nolek, S. D., Gosnell, K. J., Bagui, S. S., and Bagui, S. C.: Atmospheric deposition of mercury and major ions to the Pensacola (Florida) watershed: spatial, seasonal, and inter-annual variability, Atmos. Chem. Phys., 10, 5425-5434, doi:10.5194/acp-10-5425-2010, 2010.

Coquery, M., Cossa, D., and Sanjuan, J.: Speciation and sorption of mercury in two macro-tidal estuaries, Mar. Chem., 58, 213-227, 1997.

CAMNet, Canadian Atmospheric Mercury Measurement Network: http://www.msc.ec.gc.ca/arqp/camnet-e.cfm, 2006

China Meteorological Administration: http://www.cma.gov.cn/, last access: October 2010.

Choi, H. D., Sharac, T. J., and Holsen, T. M.: Mercury deposition in Adirondacks: A comparison between precipitation and throughfall, Atmos. Environ., 42, 1818-1827, 2008.

Fitzgerald, W. F., Mason, R. P., and Vandal, G. M.: Atmospheric cycling and air-water exchange of mercury over mid-continental lacustrine regions, Water Air Soil Poll., 56, 745, 1991.

Fu, X. W., Feng, X., Dong, Z. Q., Yin, R. S., Wang, J. X., Yang, Z. R., and Zhang, H.: Atmospheric gaseous elemental mercury (GEM) concentrations and mercury depositions at a high-altitude mountain peak in south China, Atmos. Chem. Phys., 10, 24252437, doi:10.5194/acp-10-2425-2010, 2010a.

Fu, X. W., Feng, X. B., Zhu, W., Z., Rothenberg, S., Yao, H., and Zhang, H.: Elevated atmospheric deposition and dynamics of mercury in a remote upland forest of southwestern China, Environ. Poll., 158, 2324-2333, 2010b.

Guentzel, J., Landing, W. M., Gill, G. A., and Pollman, C. D.: Processes influencing rainfall deposition of mercury in Florida, Environ. Sci. Technol., 35, 863-873, 2001.

Guo, Y. N., Feng, X. B., Li, Z. G., He, T. R., Yan, H. Y., Meng, B., Zhang J. F., and Qiu, G. L.: Distribution and wet deposition fluxes of total and methyl mercury in Wujiang reservoir Basin, Guizhou, China, Atmos. Environ., 42, 7096-7103, 2008.

Hall, B. D., Manolopoulos, H., Hurley, J. P., Schauer, J. J., St.Louis, V. L., Kenski, D., Graydon, J., Babiarz, C. L., Cleckner, L. B., and Keeler, G. J.: Methyl and total mercury in precipitation in the Great Lakes region, Atmos. Environ., 39, 7557-7569, 2005.

Hammerschmidt, C. R., Lamborg, C. H., and Fitzgerald, W. F.: Aqueous phase methylation as a potential source of methylmercury in wet deposition, Atmos. Environ., 41, 1663-1668, 2007.
Jiang, G. B., Shi, J. B., and Feng, X. B.: Mercury pollution in China. Environ. Sci. Technol., 40, 3672-3678, 2006.

Keeler, G. J., Gratz, L. E., and Al-wili, K.: Long-term atmospheric mercury wet deposition at Underhill, Vermont, Ecotoxicol., 14, 71-83, 2005.

Keeler, G. J., Landis, M. S., Norris, G. A., Christianson, E. M., and Dvonch, J. T.: Sources of mercury wet deposition in Eastern Ohio, USA, Environ. Sci. Technol., 40, 5874-5881, 2006.

Lamborg, C. H., Fitzgerald, W. F., Vandal, G. M., and Rolfhus, K. R.: Atmospheric mercury in northern Wisconsin: sources and species, Water Air and Soil Poll., 80, 189-198, 1995.

Landis, M. S. and Keeler, G. J.: Atmospheric mercury deposition to Lake Michigan during the Lake Michigan mass balance study, Environ. Sci. Technol., 36, 4518-4524, 2002.

Leermakers, M., Meuleman, C., and Baeyens, W.: Mercury distribution and fluxes in LakBaikal, in: Global and Regional Mercury Cycles: Sources, Fluxes and Mass Balances, edited by: Baeyens, W. R. G., Ebinghaus, R., and Vasiliev, O., Kluwer Academic Publishers: Dordrecht, The Netherlands, 303-315, 1996.

Li, Y., Geng, D., Dong, X. N., and Zhu, Y.: Climate change of wind speed in Chongqing from 1961 to 2007, Trans. Atmos. Sci., 33, 336-340, 2010.

Lindberg, S., Bullock, R., Ebinghaus, R., Engstrom, D., Feng, X. B., Fitzgerald, W., Pirrone, N., Prestbo, E., and Seigneur, C.: A Synthesis of Progress and Uncertainties in Attributing the Sources of Mercury in Deposition, Journal of the Human Environment, 36, 19-33, 2007.

Lombard, M. A. S., Bryce, J. G., Mao, H., and Talbot, R.: Mercury deposition in Southern New Hampshire, 2006-2009, Atmos. Chem. Phys., 11, 7657-7668, doi:10.5194/acp-11-76572011, 2011.

Lyman, S. N. and Gustin, S.: Speciation if atmospheric mercury at two sites in northern Nevada, USA, Atmos. Environ., 42, 927939, 2008.

Lynam, M. M. and Keeler, G. J.: Source-receptor relationships for atmospheric mercury in urban Detroit, Michigan, Atmos. Environ., 40, 3144-3155, 2006.

Mao, H., Talbot, R. W., Sigler, J. M., Sive, B. C., and Hegarty, J. D.: Seasonal and diurnal variations of $\mathrm{Hg}^{0}$ over New England, Atmos. Chem. Phys., 8, 1403-1421, doi:10.5194/acp-8-1403-2008, 2008.

Mason, R. P. and Sullivan, K. A.: The distribution and speciation of mercury in the South and equatorial Atlantic, Deep-Sea Res. Part II-Top. Stud. Oceanogr., 46, 937-956, 1999.

Mason, R. P., Lawson, N. M., and Sheu, G. R.: Annual and seasonal trends in mercury deposition in Maryland, Atmos. Environ., 34, 1691-1701, 2000.

Meili, M.: Mercury in Lakes and Rivers, in: Metal Ions in Biological Systems. Vol. 34: Mercury and its Effect on Environment and Biology, edited by: Sigel, A. and Sigel, H., Marcel Dekker Inc., New York, chp. 2, 21-51, 1997.

Munthe, J., Hultberg, H., and Iverfeldt, Å.: Mechanisms of deposition of methyl mercury and mercury to coniferous forests, Water Air Soil Poll., 80, 363-371, 1995a.

Munthe, J., Hultberg, H., Lee, Y.-H., Parkman, H., Iverfeldt, Å., and Renberg, I.: Trends of mercury and methyl-mercury in deposition, run-off water and sediments in relation to experimental manipulations and acidification, Water Air Soil Poll., 85, 43-48, $1995 b$. 
National Atmospheric Deposition Programme: 2006 Annual Summary, Mercury Deposition Network, available at: http://nadp. sws.uiuc.edu/lib/data/2006as.pdf, 11-14, 2007.

National Research Council: Toxicological effects of MeHg, Committee Report, Board of Environmental Studies and Toxicology, National Academy press, Washing DC, p. 344, 2001.

Nguyen, H. L., Leermakers, M., Kurunczi, S., Bazo, L., and Baeyens, W.: Mercury distribution and speciation in Lake Balaton, Hungary, Sci. Total Environ., 340, 231-246, 2005.

Rolfhus, K. R., Sakamoto, H. E., Cleckner, L. B., Stoor, R. W., Babiarz, C. L., Back, R. C., Manolopoulos H., and Hurley, J. P.: Distribution and fluxes of total and methylmercury in Lake Superior, Environ. Sci. Technol., 37, 865-872, doi:10.1021/es026065e, 2003.

Sakata, M. and Marumoto, K.: Formation of atmospheric particulate matter in the Tokyo metropolitan area, Atmos. Environ., 36, 239246, 2002.

Sakata, M. and Marumoto, K.: Wet and dry deposition fluxes of mercury in Japan, Atmos. Environ., 39, 3139-3146, 2005.

Sorensen, J., Glass, G., Schmidt, K., Huber, J., and Rapp Jr., G.: Airborne mercury deposition and watershed characteristics in relation to mercury concentrations in water, sediments, plankton, and fish of eighty northern Minnesota lakes, Environ. Sci. Technol., 24, 1716-1727, 1990.

St. Louis, V. L., Rudd, J. W. M., Kelly, C. A., Beaty, K. G., Bloom, N. S., and Flett, R. J.: Importance of wetlands as sources of methylmercury to boreal forest ecosystems, Can. J. Fish. Aquat. Sci., 51, 1065-1076, 1994.

St. Louis, V. L., Rudd, J. W. M., Kelly, C. A., and Barrie, L. A.: Wet deposition of methyl mercury in northwestern Ontsrio compared to other geographic locations, Water Air Soil Poll., 80, 405-414, 1995.

St. Louis, V. L., Sharp, M. J., Steffen, A., May, A., Barker, J., Kirk, J. A., Kelly, D. J. A., Arnott, S. E., Keatley, B., and Smol, J. P.: Some sources and sinks of monomethyl and inorganic mercury on Ellesmere Island in the Canadian High Arctic, Environ. Sci. Technol., 39, 2686-2701, 2005.

Stamenkovic, J., Lyman, S., and Gustin, M. S.: Seasonal and diel variation of atmospheric mercury concentrations in the Reno (Nevada, USA) airshed, Atmos. Environ., 41, 6662-6672, 2007.

Statistic Bureau of Chongqing: Chongqing Statistics Yearbook. Chongqing Press, 2001, 2002, 2003, 2004, 2005, 2006, 2007, 2008, 2009, 2010.
Streets D. G., Hao, J. M., Wu, Y., Jiang, J. K. Chan, M., Tian, H. Z., and Feng, X. B.: Anthropogenic mercury emissions in China, Atmos. Environ., 39, 7789-7806, 2005.

Touma, J. S., Cox, W. M., and Tikvart, J. A.: Spatial and temporal variability of ambient air toxics data, Air Waste Manage. Assoc., 56, 1716-1725, 2006.

US EPA: Method 1631: Revision E, Mercury in water by Oxidation, Purge and Trap, and Cold Vapor atomic Fluorescence Spectrometry, United States Environmental Protection Agency, 1-33, 2002

US EPA: Method 1630: Methyl mercury in water by distillation, aqueous ethylation, purge and trap, and CVAFS, U.S. Environmental Protection Agency, Office of Water, Office of Science and Technology Engineering and Analysis Division (4303), 1200 Pennsylvania Avenue NW, Washington, DC 20460, 1-41, 2001.

US EPA: Method 300: Revision 2.1, Determination of inorganic anions by ion chromatography, U.S. Environmental Protection Agency, Environmental monitoring systems laboratory office of research and development, Cincinnati, Ohio 45268, 1-28, 1993

Wan, Q., Feng, X. B., Julia, L., Zheng, W., Song, X. J., Li, P., Han, S. J., and Xu, H.: Atmospheric mercury in Changbai Mountain area, northeastern China II. The distribution of reactive gaseous mercury and particulate mercury and mercury deposition fluxes, Envrion. Res., 109, 721-727, 2009.

Wang, D. Y., He, L., Wei, S. Q., and Feng, X. B.: Estimation of mercury emission from different sources to atmosphere in Chongqing, China, Sci. Total Environ., 366, 722-728, 2006.

Wang, Q. C., Shen, W. G., and Ma, Z. W.: The estimation of mercury emission from coal combustion in China, China Environmental Science, 19, 318-321, 1999 (in Chinese with English abstract).

Wong, C. S. C., Duzgoren-Aydin, N. S., Aydin, A., and Wong, M. H.: Sources and trends of environmental mercury in Asia, Sci. Total Environ., 368, 649-662, 2006.

Wu, Y., Wang, S. X., Streets, D. G., Hao, F. M., Chan, M., and Jiang, J. K.: Trends in Anthropogenic Mercury Emissions in China from 1995 to 2003, Environ. Sci. Technol., 40, 5312-5318, 2007.

Yang, Y. K., Chen, H., and Wang, D.Y.: Spatial and temporal distribution of gaseous elemental mercury in Chongqing, China, Environ. Monit. Assess., 156, 479-489, 2009.

Zhang, L. and Wong, M. H.: Environmental mercury contamination in China: sources and impacts, Environ. Int., 33, 108-121, 2007. 